\title{
Chemical and stable isotope composition of surface and groundwater in the surroundings of the Los Humeros Caldera, Puebla, Mexico
}

\author{
Thomas Kretzschmar ${ }^{1, *}$, Matteo Lelli ${ }^{2}$, Ruth Alfaro $^{3}$, Juan Ignacio Sanchez ${ }^{1}$, and Yann \\ Rene Ramos ${ }^{4}$ \\ ${ }^{1}$ Departamento de Geología, Centro de Investigación y Educación Superior de Ensenada (CICESE) \\ Ensenada, Mexico \\ ${ }^{2}$ Istituto de Geocienze y Georizore, CNR, Pisa Italy \\ ${ }^{3}$ Instituto de Investigaciones Quimico Biologicas, Universidad Michocana de San Nicolas Hidalgo \\ (UMSNH) Morelia, Mexico, \\ ${ }^{4}$ Departamento de Ingeniería Geomática y Hidráulica, Universidad de Guanajuato, Guanajuato, \\ Mexico
}

\begin{abstract}
It is important to develop a regional hydrogeological model to identify possible recharge and discharge areas for a sustainable use of a geothermal reservoir. The Los Humeros geothermal area is situated within five surficial watersheds and coveres an area of more than $15.000 \mathrm{~km}^{2}$. A total of 208 well and spring samples were collected between June 2017 and November 2018. The stable isotope data for this region define a regression line of $\delta \mathrm{D}_{\mathrm{H} 2 \mathrm{O}}=8.032 \cdot \delta^{18} \mathrm{O}+12$ and indicate that groundwater is recharged by regional precipitation. At least 39 groundwater wells, with a maximum temperature of $35^{\circ} \mathrm{C}$, show temperatures above the reported mean average surface temperature of $15^{\circ} \mathrm{C}$. Characteristic elements for geothermal reservoir fluids $(\mathrm{B}, \mathrm{Li}, \mathrm{As})$ are also present in these groundwaters, indicating a possible connection between the reservoir fluid and the local groundwater through local fracture systems. Concentration of B in these hot wells is between 150 and $35000 \mathrm{ppb}$.
\end{abstract}

\section{Introduction}

The geothermal field of Los Humeros is one of the four geothermal energy exploitation areas under the responsibility of the Federal Electricity Commission (CFE in Spanish). The field has been in production since 1990 and currently generates 68.6 MW. As part of the GeMEX project approved at the end of 2016, different sub-projects are being carried out in this area, one of which is the development of a hydrogeological model for the Los Humeros region. The area covered by this work includes five different hydrological basins that cover more than $15,000 \mathrm{~km}^{2}$ (Fig. 1). Recent geological studies at the Los Humeros Caldera include one by Carrasco et al., 2017 [1] that addressed the subsurface stratigraphy and its correlation to the surficial geology of the area, and another by Norini et al., 2015 [2] that focused on structural and thermal remote sensing of the LH volcanic complex. An earlier hydrogeological study examined local conditions around the Los Humeros caldera [3] and an internal study by CFE was the only regional-scale study that included possible recharge areas for the Los Humeros geothermal reservoir [4]. Evaluations of the aquifers in the

\footnotetext{
* Corresponding author: tkretzsc@ cicese.mx
} 
watersheds surrounding Los Humeros were reported by the National Water Authority (CNA in Spanish, [5-7]). These studies identified the aquifers present in the different watersheds and estimated approximate water balances.

Hydrochemical analysis and the stable isotope composition of water $\left(\delta \mathrm{D}_{\mathrm{H} 2 \mathrm{O}}\right.$ and $\delta^{18} \mathrm{O}_{\mathrm{H} 2 \mathrm{O}}$ ) are widely used as tracers to determine recharge and flow paths within watersheds. Furthermore, they are helpful in identifying mixing processes, the evolution of the groundwater within an aquifer, and extent of water-rock interaction. The goal of this study was to identify the recharge areas within the watersheds of the Los Humeros geothermal area and to develop a regional scale hydrogeological, hydrogeochemical model by linking the water budget of the surficial watersheds to the groundwater movement and further to the deep geothermal reservoir.

\section{Methodology}

\subsection{Study area}

The study area consists of the Los Humeros geothermal field (Fig. 1), within the Los Humeros volcanic caldera, and its surroundings within a radius of $\sim 4$ to $65 \mathrm{~km}$ of the caldera boundary. The geothermal field is located in the northeastern part of the State of Puebla, $200 \mathrm{~km}$ southeast of Mexico City (latitude $19^{\circ} 40^{\prime} \mathrm{N}$ and longitude $97^{\circ} 25^{\prime} \mathrm{W}$ ). It is located in the eastern sector of the Mexican Volcanic Belt, within a basin bordering the states of Veracruz and Tlaxcala. The geothermal field has an elevation of $\sim 3000 \mathrm{~m}$ a.m.s.l. and is bounded by Los Potreros caldera, which is part of the caldera volcanic complex (towards the central zone).

The Los Humeros volcanic caldera of is the largest active caldera-type complex in the Mexican Volcanic Belt. It includes the Los Humeros caldera of $(\sim 15 \times 21 \mathrm{~km})$ and nested within it, Los Potreros caldera $(\sim 10 \mathrm{~km}$ in diameter) $[1,8]$. The basement of the region consists of Paleozoic-Mesozoic granites, granodiorites, and schists that are overlain by Mesozoic continental and marine sedimentary rocks. Regional folding formed the Sierra Madre Oriental mountain range as a consequence of SW-NE tectonic compression during the Laramide orogeny at the end of the Early Paleocene-Eocene. Igneous intrusion occurred during this folding, along with emplacement of acid igneous rocks through weak zones along fractures and faults.

There are two shallow aquifers in the region, one that is cold and the other that is warm. These are hosted in strata composed of basalts, tuffs and andesites of high permeability [3]. According to a NNW-SSE orientated lithological section made by Arellano et al. [9], these units were identified as permeable horizons within strata of basalts, andesites, and metamorphic limestones, the latter having high primary permeability. Groundwater is confined laterally by the Los Potreros and Los Humeros collapse structures. Thus, groundwater discharge occurs through the faults and fractures that have produced the secondary permeability of the system. Groundwater water flow is directed toward depth due to these hydraulic connections, which allows descending water to reach the geothermal reservoir and recharge it. Recharge of shallow waters occurs within the endorheic basin of Los Humeros. These waters do not have a hydraulic connection with deep wells, water wells, or springs around Los Humeros, so local rainfall is the recharge system in the area $[3,10]$.

\subsection{Chemical and isotopic analyses}

In the initial collection of June 2017, a total of 55 springs, wells, and streams were sampled, with priority given to areas with recharge potential to the carbonates that form the basement 
of Los Humeros [2]. Further sampling campaigns were carried out in November 2017 (18 samples), March 2018 (85 samples), and November-December 2018 (50 samples). Electrical conductivity (EC), alkalinity, $\mathrm{pH}$, dissolved oxygen and when possible the runoff or discharge were determined in the field at the time of sampling. The samples were later analyzed in the laboratory for anions $\left(\mathrm{Cl}, \mathrm{NO}_{3}, \mathrm{SO}_{4}, \mathrm{PO}_{4}\right.$ and $\mathrm{F}$ ), major cations $(\mathrm{Na}, \mathrm{Ca}, \mathrm{K}$, $\mathrm{Mg}, \mathrm{Si}$ ), minor cations (Fe, $\mathrm{Mn}, \mathrm{Sr}, \mathrm{Li}$ ), and trace elements (Al, Ni, $\mathrm{Cu}, \mathrm{Cd}, \mathrm{As}, \mathrm{Se}, \mathrm{Ti}$, among others). TH- and O- isotope compositions were also measured for all samples. Duplicates samples were collected; one set (except tritium) was analyzed in the facilities of the CeMIE-Geo in Ensenada and the other in the laboratories of CNR in Pisa, Italy.

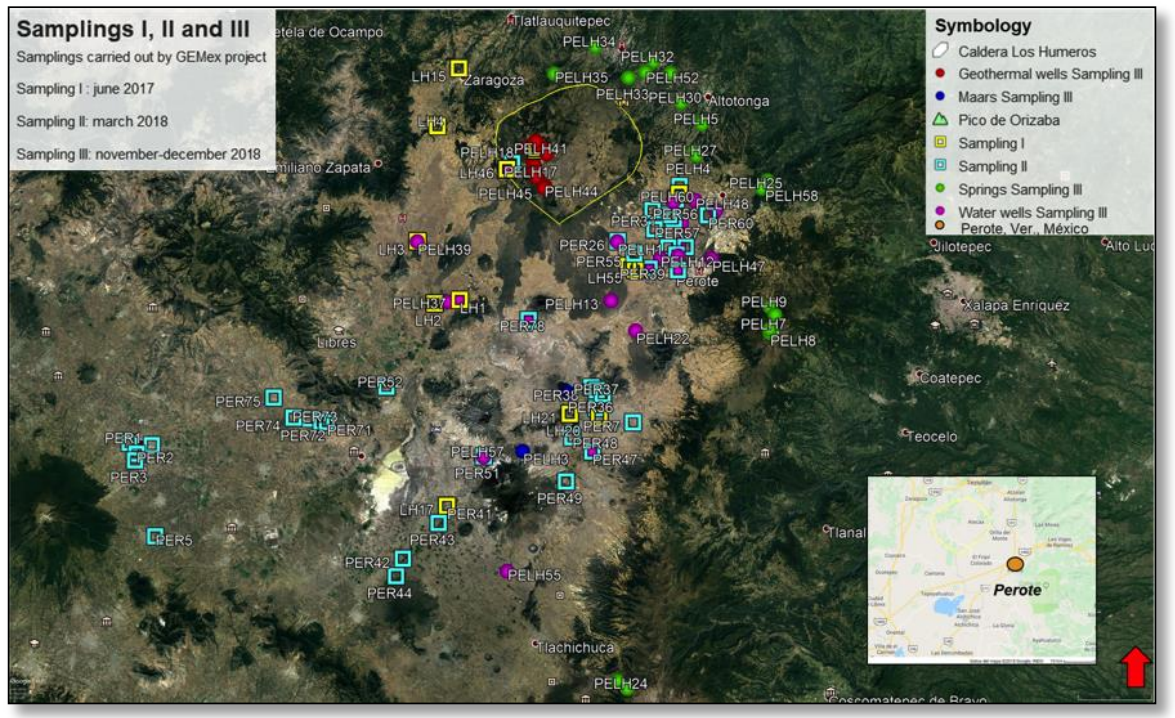

Fig. 1. Location map of the Los Humeros region showing GEMex sampling points in June 2017 (sampling I), March 2018 (sampling II), and November-December 2018 (sampling III): Symbols: Caldera Los Humeros (yellow line), Sampling I (yellow squares), Sampling II (blue squares), and Sampling III (circles; geothermal wells (red circles), springs (green circles), water wells (magenta circles), maars (navy blue).

\section{Results and discussion}

The respective temperature ranges of the wells and springs of the Los Humeros region permitted a division of the samples into four groups: cold springs (63 samples), hot spring (1 samples), wells with lower than mean average air temperature (30 samples; cold wells), and wells with higher than mean average air temperature (39 samples; hot wells). The cold springs (temperature up to $20^{\circ} \mathrm{C}$ ) had electrical conductivity (EC) that varied between 29 and $600 \mu \mathrm{S} / \mathrm{cm}, \mathrm{pH}$ values between 6.44 and 7.57, and alkalinity between 30 and $90 \mathrm{mg} / \mathrm{L}$. The hot spring with temperature up to $39.1^{\circ} \mathrm{C}$, had higher EC $(1600 \mu \mathrm{S} / \mathrm{cm})$ than the cold springs, and was more similar to two of the hot wells (temperature of $35^{\circ} \mathrm{C}$ ) with EC of 1760 and $1870 \mu \mathrm{S} / \mathrm{cm}$. However, EC was as high as $1870 \mu \mathrm{S} / \mathrm{cm}$ in the cold wells, although most of the cold wells had an EC of less than $600 \mu \mathrm{S} / \mathrm{cm}$. The $\mathrm{pH}$ of these wells varies between 6.7 and 7.7 and the alkalinity between 200 and $660 \mathrm{mg} / \mathrm{L}$.

Thirty-nine wells in the study site had temperatures above the mean average air temperature of $15{ }^{\circ} \mathrm{C}$ [5]; the highest measured temperature was almost $35{ }^{\circ} \mathrm{C}$ in a $160 \mathrm{~m}$ deep agricultural well. The majority of wells have a depth between 150 and $300 \mathrm{~m}$ and fall in the 22 to $27^{\circ} \mathrm{C}$ range. Theses wells can be divided into two groups, one with EC below 
$250 \mu \mathrm{S} / \mathrm{cm}$ and the other with EC of up to $600 \mu \mathrm{S} / \mathrm{cm}$. The low EC wells are mainly springs that have small catchment areas, are of a $\mathrm{Ca}-\mathrm{HCO}_{3}$ type, and emanate from carbonate rocks. The higher EC wells have larger catchment areas, longer groundwater residence times, or volcanic settings. Only a few of the springs, all of which are predominantly of an intermediate type, are located in volcanic rocks.

Table 1 summarizes some of the physiochemical and hydrochemical parameters, together with the stable isotope composition of the different groups. As expected, the springs exhibit low concentrations of major ions and can be clearly separated from the hot spring, which has higher concentrations of major and minor elements. The hot spring is dominated by Ca $(230 \mathrm{mg} / \mathrm{L})$, $\mathrm{SO}_{4}(660 \mathrm{mg} / \mathrm{L})$, and has high amounts in $\mathrm{Sr}(5.9 \mathrm{mg} / \mathrm{L})$, which together reflect a sedimentary recharge area much longer residence time. Some of the cold springs have high concentrations in $\mathrm{NO}_{3}$, which likely reflects an input from anthropogenic contamination. Contents of $\mathrm{NO}_{3}{ }^{-}$, when detected, range between 1.8 and $32.4 \mathrm{mg} / \mathrm{L}$.

The hot and cold wells have a contrasting chemical character and exhibit differences in key parameters (e.g. Li, As, B), which are indicators for higher temperatures and/or longer subsurface residence times. The maximum B content measured was $35 \mathrm{ppm}$ and high B concentrations were observed in most of the hot wells, with concentrations at least $50 \%$ higher than in the cold wells. Concentrations of B in Los Humeros injection wells were as observed to be $420 \mathrm{mg} / \mathrm{L}$ or higher. B isotope compositions will be determined to correlate between the reservoir and the hot wells. Li concentrations in the hot wells range between 32 to $520 \mathrm{ppb}$ and from below detection to $21.3 \mathrm{ppb}$ in the cold wells. Concentrations of As, which is considered to be another indicator for a thermal signature, are not consistently different in the hot and cold wells.

Table 1. Summary of chemical and stable isotopic compositions for groundwaters of the Los Humeros region. EC: electrical conductivity. $\mathrm{Na}^{+}$, and $\mathrm{Cl}^{-}$concentrations in $\mathrm{mg} / \mathrm{L}$ and $\mathrm{B}$ in $\mathrm{ppb}$. $\mathrm{BD}=$ below detection. Values of $\delta \mathrm{D}_{2} \mathrm{O}$ and $\delta^{18} \mathrm{OH} 2 \mathrm{O}$ are expressed in permil relative to VSMOW.

\begin{tabular}{|l|c|c|c|c|c|c|c|c|}
\hline Group & $\mathbf{T}^{\mathbf{}} \mathbf{C}$ & $\mathbf{p H}$ & $\begin{array}{c}\mathbf{E C} \\
(\boldsymbol{\mu} \mathbf{S} / \mathbf{c m})\end{array}$ & $\begin{array}{c}\mathbf{N a}^{+} \\
(\mathbf{m g} / \mathbf{L})\end{array}$ & $\mathbf{C l}^{-}(\mathbf{m g} / \mathbf{L})$ & $\mathbf{B}(\mathbf{p p b})$ & $\boldsymbol{\delta}^{\mathbf{1 8}} \mathbf{O}_{\mathbf{H} 20}$ & $\boldsymbol{\delta}_{\mathbf{H} 20}$ \\
\hline Springs & $\begin{array}{c}9.3 \text { to } \\
16.5\end{array}$ & $\begin{array}{c}6.44 \text { to } \\
7.94\end{array}$ & 29 to 205 & $\begin{array}{c}1.73 \text { to } \\
30.36\end{array}$ & BD to 14.1 & BD to 35 & $\begin{array}{c}-14.11 \text { to } \\
-8.21\end{array}$ & $\begin{array}{c}-98.8 \text { to } \\
-50.2\end{array}$ \\
\hline $\begin{array}{l}\text { Hot } \\
\text { Spring }\end{array}$ & 39.1 & 6.7 & 1600 & 29.4 & 43.2 & 160 & $\begin{array}{c}-7.74 \pm \\
0.04\end{array}$ & $-78.7 \pm 0.2$ \\
\hline $\begin{array}{l}\text { Cold } \\
\text { wells }\end{array}$ & $\begin{array}{c}14.5 \text { to } \\
18.3\end{array}$ & $\begin{array}{c}6.7 \text { to } \\
7.7\end{array}$ & $\begin{array}{c}550 \text { to } \\
1870\end{array}$ & $\begin{array}{c}5.12 \\
\text { to120.2 }\end{array}$ & 6.8 to 193 & BD to 100 & $\begin{array}{c}--13.24 \text { to } \\
-10.23\end{array}$ & $\begin{array}{c}-94.5 \text { to } \\
-72.8\end{array}$ \\
\hline $\begin{array}{l}\text { Hot } \\
\text { wells }\end{array}$ & $\begin{array}{c}20.2 \text { to } \\
34.9\end{array}$ & $\begin{array}{c}6.32 \text { to } \\
8.2\end{array}$ & $\begin{array}{c}440 \text { to } \\
6000\end{array}$ & $\begin{array}{c}5.12- \\
\text { to905 }\end{array}$ & $1.16 \pm 1170$ & $\begin{array}{c}150 \text { to } \\
35000\end{array}$ & $\begin{array}{c}-12.61 \text { to } \\
-9.02\end{array}$ & $\begin{array}{c}-90.0 \\
-68.6\end{array}$ \\
\hline
\end{tabular}

The stable isotope compositions for Los Humeros groundwaters fall approximately along the Global Meteoric Water Line (GMWL), defining a Local Meteoric Water Line of $\delta \mathrm{D}_{\mathrm{H} 2 \mathrm{O}}$ $=8.315 \delta^{18} \mathrm{O}_{\mathrm{H} 2 \mathrm{O}}+12$ that is only slightly shifted from the GMWL (Fig. 2). Samples displaced away from the main $\delta \mathrm{D}-\delta^{18} \mathrm{O}$ data array to higher $\delta^{18} \mathrm{O}$ values in Figure are the hot wells and hot spring discharging waters that have undergone substantial water-rock interaction at elevated temperature during their subsurface residence.

\section{Conclusions}

The hydrochemical and stable isotope results on the sampled sites show, first that the most of the groundwater is directly related to regional recharge from precipitation in the area. However, it was observed that at least some groundwater is likely mixing with fluids emanating from the geothermal reservoir. The indicators for this behaviour are elevated temperatures in at least 39 wells, the presence of significant concentrations of $\mathrm{B}, \mathrm{As}$ and $\mathrm{Li}$ compared to waters from the cold wells, and ${ }^{18} \mathrm{O}$ enrichment in the hottest waters. These 
findings coincide with the presence of a regional fault close to these sites. B isotopes and organic compounds will be measured in the future to further characterize this geothermalreservoir discharge.

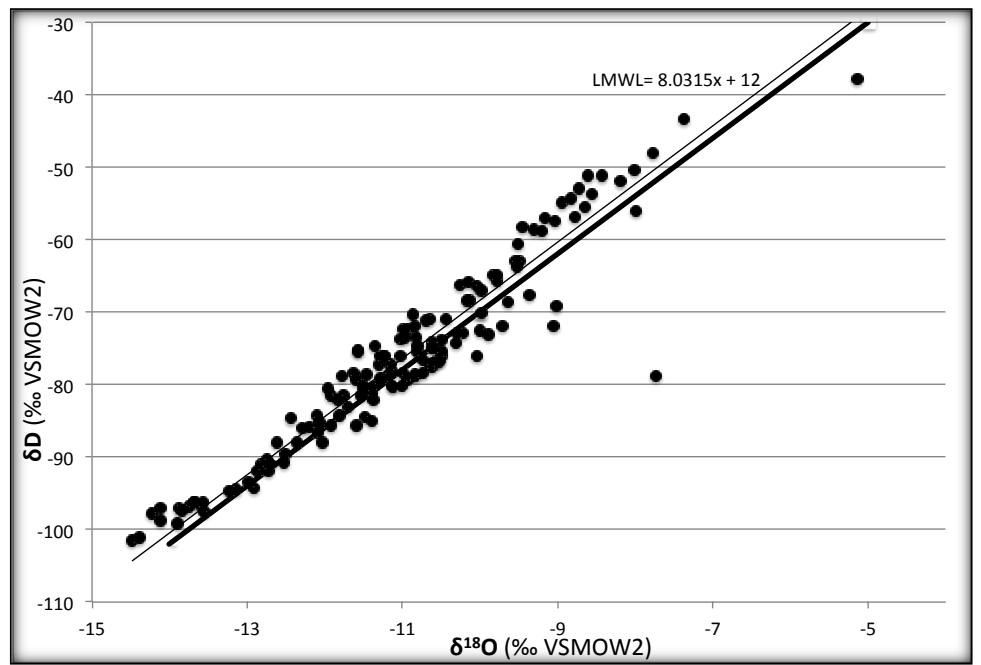

Fig. 2. Plot of $\delta$ Dн2о versus $\delta^{18}$ Онго plot showing the isotopic composition of springs and wells sampled in the Los Humeros geothermal area. Solid line $=$ GMWL from [11]. The local Meteoric Water Line (LMWL) for the Los Humeros area is $\delta \mathrm{D}=8.032 \delta^{18} \mathrm{O}+12$.

This work was financed by the GeMEX project, a joint Mexican-EU research project regarding supercritical and EGS geothermal sites in Mexico. We also want to thank the Federal Electricity Commission for their support and access to their installations.

\section{References}

1. G. Carrasco-Núñez, et al., Geothermics, 67, 1-17 (2017)

2. G. Norini, et al., J Volcan Geoth Res, 301, 221-237 (2015)

3. E. Portugal, et al., Geofís Int, 41, 415-420 (2002)

4. CFE, Estudio Geohidrológico En El Campo Geotérmico De Los Humeros, Puebla. 258 (2014)

5. CNA, Actualización De La Disponibilidad Media Anual De Agua En El Acuífero, Libres-Oriental 2012, Estado de Puebla, 13 (2015)

6. CNA, Actualización De La Disponibilidad Media Anual De Agua En El Acuífero Tecolutla 3002, Estado de Veracruz. 27 (2015)

7. CNA, Actualización De La Disponibilidad Media Anual De Agua En El Acuífero Perote-Zalayeta, 3004, Estado de Veracruz, 27 (2015)

8. L. Peiffer, et al., J Volcan Geoth Res, 356, 163-174 (2018)

9. V.M. Arellano, et al., J Volcan Geoth Res, 124, 67-88 (2003)

10. R.F Cedillo, Proc World Geoth Congr 2000, 1639-1644 (2000)

11. H. Craig, Science, 133, 1702-1703 (1961) 